NBER WORKING PAPER SERIES

ARE NATIONAL PATENT LAWS THE BLOSSOMING RAIN?

Yi Qian

Working Paper 16295

http://www.nber.org/papers/w16295

\author{
NATIONAL BUREAU OF ECONOMIC RESEARCH \\ 1050 Massachusetts Avenue \\ Cambridge, MA 02138 \\ August 2010
}

I would like to give my special thanks to Professors Richard Caves, Donald Rubin, Josh Lerner, and Richard Cooper for their constant advice and encouragement; to Drs. Arvind Subramanian, Jayashree Watal, Gary Haufbauer, and Keith Maskus for their advice and references at early stages of my research; to Professors Andrei Shleifer, Paul Beamish, and Dr. Fritz Foley for providing data. Many thanks also go to Professors Neil Netanel and Robert Spich for organizing the IPR symposium at UCLA and to the participants' comments, which stimulated new idea developments in this paper. I am also grateful to Neil Netanel for editing this book and for his comments on this chapter in The Development Agenda: Global Intellectual Property and Developing Countries. Oxford University Press, London. The views expressed herein are those of the author and do not necessarily reflect the views of the National Bureau of Economic Research.

NBER working papers are circulated for discussion and comment purposes. They have not been peerreviewed or been subject to the review by the NBER Board of Directors that accompanies official NBER publications.

(C) 2010 by Yi Qian. All rights reserved. Short sections of text, not to exceed two paragraphs, may be quoted without explicit permission provided that full credit, including $\odot$ notice, is given to the source. 
Are National Patent Laws the Blossoming Rain?

Yi Qian

NBER Working Paper No. 16295

August 2010

JEL No. O34

\begin{abstract}
Research on the effects of patent protection on innovation and technology transfer in the cross-country pharmaceutical industry adds to our understanding of the underlying forces driving a country's innovation level. Qian (2007) constructs a comprehensive database useful for evaluating the patenting effects on pharmaceutical innovations for 26 countries that established national pharmaceutical patent laws during the period from 1978 to 2002 . This paper is a companion piece that extends the research to evaluating the effects of patent reforms on inward foreign direct investment (FDI) establishments and imports in the pharmaceutical sectors. This book chapter also attempts to integrate all the findings on innovations, technology transfer, and international trade, and discuss potential policy implications.

By thoroughly controlling for the country covariates, through a combination of matched sampling techniques with fixed-effect panel regression models, the analyses arrive at robust results across the various model specifications. First, national pharmaceutical patent protection alone does not stimulate domestic innovation, as estimated by the US patent awards (both raw counts and citation-weighted) and domestic R\&D. FDI establishments and pharmaceutical exports did not increase significantly either. Imports, however, did flourish. Second, national patent law implementation demonstrates conditional importance for innovation acceleration and technology transfer, conditional upon certain country variables. In particular, the interaction between implementation and the development level, educational attainment, and economic freedom index are shown to have positive relationships with the domestic R\&D expenditure and domestic pharmaceutical patent awards in the US. The interaction between implementation and economic freedom, implementation and educational attainment are indicated to attract more FDI establishments. Third, terms of trade is likely to decline immediately upon the new implementation of IPR.
\end{abstract}

Yi Qian

Department of Marketing

Kellogg School of Management

Northwestern University

2001 Sheridan Road

Evanston, IL 60208

and NBER

yiqian@kellogg.northwestern.edu 


\title{
Are National Patent Laws the Blossoming Rains?
}

\author{
Evidence from Domestic Innovation, Technology Transfers, and \\ International Trade Post Patent Implementations in the Period 1978-2002
}

\section{Yi Qian*}

\author{
Kellogg School of Management \\ and NBER
}

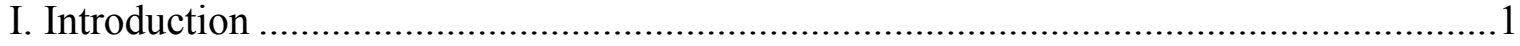

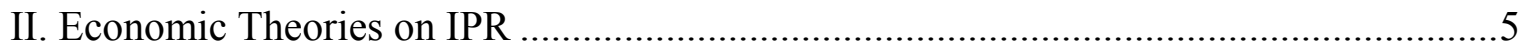

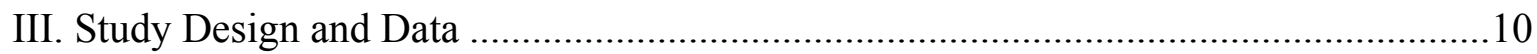

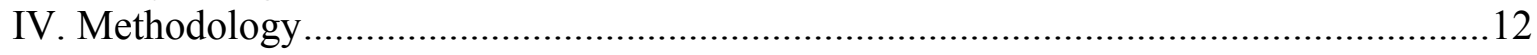

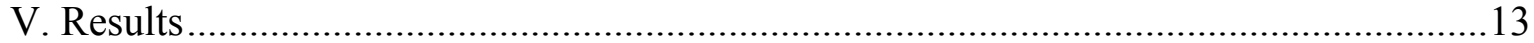

A. Patenting Effects on Innovation — Summarizing Results from Qian (2007) ...13

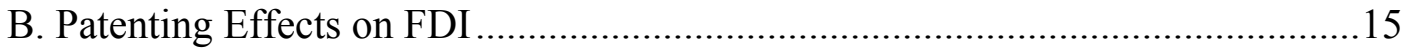

C. Patenting Effects on Imports ..................................................................... 16

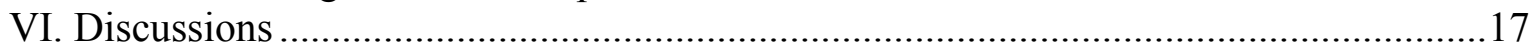

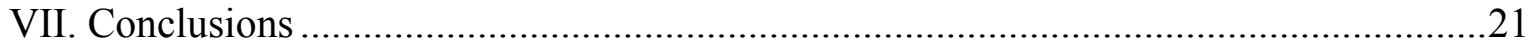

\section{INTRODUCTION}

The rationale for patent protection is that patentees who gain exclusive marketing rights to their innovations can reap the benefits, and recoup the costs, of their R\&D investments; such a policy creates the incentive to innovate. The actual effect of intellectual property rights (IPRs) on innovation, however, remains one of the most controversial questions in the economics of

\footnotetext{
${ }^{*}$ I would like to give my special thanks to Professors Richard Caves, Donald Rubin, Josh Lerner, and Richard Cooper for their constant advice and encouragement; to Drs. Arvind Subramanian, Jayashree Watal, Gary Haufbauer, and Keith Maskus for their advice and references at early stages of my research; to Professors Andrei Shleifer, Paul Beamish, and Dr. Fritz Foley for providing data. Many thanks also go to Professors Neil Netanel and Robert Spich for organizing the IPR symposium at UCLA and to the participants' comments, which stimulated new idea developments in this paper. I am also grateful to Neil Netanel for editing this book and for his comments on this chapter in The Development Agenda: Global Intellectual Property and Developing Countries. Oxford University Press, London.
} 
technology. ${ }^{1}$ National patent policies have also been advocated to developing countries as a means of attracting foreign direct investment and technology transfers. Although the World Trade Organization's (WTO) Trade-Related Aspects of Intellectual Property Rights ${ }^{2}$ (TRIPs) negotiations were successfully concluded in late 1993, the question of whether national intellectual property rights protections are beneficial to developing countries still provokes heated debate. Does such legislation stimulate enough innovation and technology transfer to justify the economic, political, and social costs associated with patent-law implementation and enforcement?

In a global patenting environment, national patent-law implementation in developing countries could bring domestic welfare gains if the new laws stimulate more domestic innovation and attract more effective foreign direct investment (FDI), bringing, in turn, advanced technology and technical know-how. This paper studies the effects of new implementation of a nation's pharmaceutical patent policy on technology transfer and international trade, and synthesizes in the effect estimates on innovation outcomes in Qian (2007). The analyses cover a sample of 92 countries from 1978 to 2002, including annual observations for a set of country covariates, as in Qian (2007). Here, technology transfer is primarily proxied by FDI establishments — the subsidiaries established by multinational corporations (MNCs) in the country of interest. Imports are sometimes considered means of technology transfer, too, if importers are able to reverse engineer the imported products and learn from them, or if the imported equipment can impart advanced techniques. An innovation is typically a new chemical entity that satisfies the regulatory agency's efficacy and efficiency requirements, or "a molecular manipulation of a known drug that yields significant benefits" (Taggart 1993, p. 14). Qian (2007) uses three alternative estimates to measure innovations: U.S. patents awarded to a particular country of origin, R\&D expenditures by a country's pharmaceutical industry, and the country's pharmaceutical exports. I summarize the

\footnotetext{
${ }^{1}$ Please see Jaffe 2000 for a detailed review on the vast literature.

${ }^{2}$ Intellectual property rights are a category of law that generally include patents, copyrights, trademarks, geographical indications, industrial designs, utility models, plant-breeder rights, integrated-circuits rights and trade secrets.
} 
findings from that paper and draw out implications jointly with the new results obtained in the current study.

This study adopts the methodological innovations in Qian (2007): that is, panel analyses of patent effects on matched country pairs. First, fixed-effects regressions on matched country pairs control more thoroughly for observed country characteristics. Second, non-parametric matching methods easily accommodate a large number of control covariates; this, in turn, enables the succeeding estimation to control for many observable country characteristics that are correlated with a country's innovative potential and patent implementation. ${ }^{3}$ Combining these two procedures may reduce biases in the patent effect estimate. The main findings in Qian (2007) are that, in the group of sampled countries, the implementation of patent laws alone does not promptly stimulate domestic innovation. However, national patent laws in combination with high levels of development, education, and economic freedom do have a positive effect on innovation. Qian (2007) also provides some of the first empirical support for the theory that the relationship between innovation and the strength of intellectual property rights is an "inverted U" shape (Gallini 1992, Cadot and Lippman 1995, Horwitz and Lai 1996). In particular, an optimal level of intellectual property rights strength appears to exist, above which additional strengthening measures actually tend to discourage innovation.

This companion study finds that U.S. and Japanese FDI establishments in the pharmaceutical industry did not increase significantly in countries where new national pharmaceutical patent laws were implemented, using the same dataset as collected in Qian (2007). The interaction effects between patent implementation, education attainment, and economic freedom are again found to be positively related to increases in FDI establishments a year after the patent reforms. Imports expanded over years. Coupled with the finding that pharmaceutical exports did not increase significantly post patent reform (Qian 2007), the results on imports imply the terms

\footnotetext{
${ }^{3}$ A country legally implements patent protection for a particular sector.
} 
of trade worsened after the countries implemented new patent laws, mirroring the findings in Scherer and Weisburst (1995).

Countries at various stages of development began to implement or extend their national intellectual property rights protections ${ }^{4}$ since the 1980 s, some voluntarily and others under pressure. The U.S. pressed developing countries' to implement patents not only through direct bilateral trade threats, ${ }^{5}$ but also through indirect multilateral pressure, particularly by bringing intellectual property rights to the agenda of the Uruguay Round negotiations of the WTO. The impact of patent protection on innovation and technology transfer is, therefore, an important policy question — one that is especially pertinent for developing countries. However, only a few studies have been done for non-OECD (Organization for Economic Cooperation and Development) countries (Lerner 2000, Branstetter et al. 2006, Qian 2007), mainly because of the difficulty in collecting data. Furthermore, some previous studies of intellectual property rights in developing countries tested their effects on innovation or technology transfers for the whole economy. This is potentially problematic because patent protection may have different effects in different industries. For instance, surveying 650 U.S. firms, Levin et al. (1986) found patenting important mainly in the pharmaceutical industry, where copying is easy.

A few empirical studies have tested the effect of patent protection on countries' pharmaceutical innovation or technology transfer, with inconclusive results. Pazderka (1999), the Patented Medicines Prices Review Board (PMPRB 1997), and McFetridge (1997) each found a statistically significant increase in pharmaceutical R\&D expenditure after the tightening of

\footnotetext{
${ }^{4}$ At least 40 developing countries lacked pharmaceutical-product patent protection as of the late $1980 \mathrm{~s}^{4}$ (Siebeck et al. 1990). By the end of 1999, however, only 16 W'TO member countries excluded pharmaceuticals from national patent protection (Scherer and Watal 2000).

${ }^{5}$ The U.S. Congress enacted legislation in 1988 that required the U.S. trade representative to annually identify such countries in the "Priority Watch List" of the "Super-301" trade report and take unilateral trade sanctions against those countries not assisting in the protection of U.S. patent rights. These threats were credible. One example is the increasing U.S. tariff on Brazilian imports in 1989 in retaliation to Brazil's copying of patented drugs (Lanjouw and Cockburn 2000). Similarly, the threat of U.S. trade action, rather than internal factors, pushed forward South Korea's decision to strengthen its intellectual property rights (McFetridge 1997, p. 3).
} 
Canadian pharmaceutical patent protection in $1987 .{ }^{6}$ In contrast, Scherer and Weisburst (1995) showed that the Italian pharmaceutical patent legislation of 1978 did not increase R\&D expenditures. Instead, it seemed to have worsened Italy's terms of trade. Challu (1995) also demonstrated a decline in new chemical entities introduced in Italy post patent protection.

These inconsistent and inconclusive results provide little consensus on the general effects of augmenting national patent protection. Because we cannot observe counterfactual outcomes of patent protection, international comparisons provide valuable leverage for analysis. There have been some cross-country studies related to IPR. To name a few, Maskus and Penubarti (1995) found IPR had a strong positive effect on imports, and Smith (1999 and 2001) reports results that are consistent with IPR's encouragement of U.S. exports. Maskus and Eby-Konan (1994) find no effect of IPR on FDI. Maskus (1998) reports regressions that are consistent with a positive effect of IPR on FDI, but only for more developed countries. Branstetter, Fisman and Foley (2006) find positive impacts of IPR on FDI using unique panel data of U.S. multinational corporations. Yang and Maskus (2001) examine the impact of IPR on technology licensing. While these studies are very interesting, results are again pooled across sectors, with the exception of the Branstetter et al. study which controls for firm fixed effects. The passage of national pharmaceutical patent laws in a group of countries in the 1980s and 1990s creates a natural experiment to test the economic impact of patent protection.

The remainder of the paper is structured as follows: Section II introduces a graphical approach to illustrate the theories and policy issues. For technically inclined readers, section III describes the study design, and briefly motivates the choice of data and methodology employed. The model is laid out in section IV. Section V presents the main empirical findings. Discussions

\footnotetext{
${ }^{6}$ Nonetheless, all these studies point out that the dramatic increase in the R\&D-spending growth rate is also attributable to the commitment of expanding R\&D by PMAC member companies in order to facilitate the passage of Canadian patent legislation. This commitment to raise their R\&D-to-sales ratio to $10 \%$ by 1996 was satisfied in 1993 , and the rate of growth in R\&D spending in these companies slowed substantially in the period from 1994 to 1997 (McFetridge 1996).
} 
and policy implications are addressed in section VI. Finally, section VII summarizes the main approach and results, and makes recommendations for future studies. Practitioners can feel free to skim through section II and focus on the results and discussions in sections V-VII.

\section{ECONOMIC THEORIES ON IPR}

Faith in patent systems is related to Schumpeter's (1942) revolutionary idea that large-scale firms with monopoly power can be a superior market structure to perfect competition. The practical effects of patent protection on innovation, however, have been controversial. It has been argued that patent systems are irrelevant for appropriating returns on investment in an era where product life cycles are shorter than patent processing times. Patents may even be counterproductive, incurring additional application costs, and promoting litigation, defensive behavior, and wasteful invention around patents ${ }^{7}$ (Jaffe and Lerner 2004). Patent laws could also block spillover effects in sequential innovations, where each innovation is built upon its predecessors, by fostering high licensing fees and races for licensing (Scotchmer and Green 1990). While the negative correlation between tightening IPR and innovation is found empirically in Bessen and Maskin (1999) and Sakakibara and Branstetter (1999), it is not supported in Kortum and Lerner (1998). The hypothesis of whether patent protection stimulates innovation deserves continuing attention.

Although a series of surveys conducted in the U.S. (Taylor and Silberston 1973, Mansfield et al. 1981, Levin et al. 1987) and Switzerland (Harabi 1997) uniformly establish the importance of patents for pharmaceutical innovations relative to other industries, it is not clear how much patent protection is optimal. One could argue that sufficient incentives to innovate are already ensured through well-established patent systems in the major markets, such as the U.S. and European

\footnotetext{
7 "Inventing around a patent" occurs when imitators attempt to avoid patent-protection and licensing rules by making small modifications on the original innovation. The disclosure of technical details required in granting a patent helps this activity.
} 
markets, and that additional patent laws in developing countries might not stimulate much more innovation, given their limited capacity to innovate domestically. Counter-arguments propose that additional pharmaceutical patent laws provide a favorable local environment for domestic inventors with firsthand knowledge of country-specific diseases. A four-phase diagram ${ }^{8}$ illustrates the static and dynamic welfare changes. The four figures represent four different phases of a particular pharmaceutical process or product supply associated with the national patent legislation change: Phase One prior to national patent implementation, Phase Two when static impacts immediately follow the national patent legislation, Phase Three when possible dynamic developments are felt after patent legislation, and Phase Four when the particular patent has expired.

For simplicity, linear demand and supply relationships are assumed. It helps to concentrate first on cost-reducing innovations, ${ }^{9}$ which seem to represent the majority of pharmaceutical innovations. A discussion of the case where there is no existing medicine in Phase One will follow later in this section. In Phase One, $\mathrm{P}_{\mathrm{w}}$ is the world monopoly price of a foreign patented drug, and $\mathrm{P}_{\mathrm{d}}$ is the domestic competitive price of its generic equivalent drug. Domestic consumers alone purchase the drug at price $\mathrm{P}_{\mathrm{d}}$, and enjoy their surplus triangle $\mathrm{AB}_{1} \mathrm{C}_{1}$. The domestic-producer surplus is zero, assuming a perfectly competitive industry with many imitators. ${ }^{10}$ (See Figure 1 in the appendix.)

In Phase Two, domestic imitative production is prohibited, and the foreign innovator charges a monopoly price at $\mathrm{P}_{\mathrm{w}}{ }^{11}$ (Figure 2). Consumer surplus shrinks to $\mathrm{AB}_{2} \mathrm{C}_{2}$, foreign

\footnotetext{
${ }^{8}$ Subramanian (1991) motivates the development of this set of graphs. As in the original Schumpeterian model, this set of graphs directly depicts the process innovation, but the economic implications apply similarly for product innovations.

${ }^{9}$ Such innovations include the development of new drugs that are less costly to produce or more effective than the existing drugs used in therapy: In both cases, innovations improve consumer surplus.

10 This assumption is practically applicable in many developing countries. For instance, Lanjouw (1998) accounts for the competitiveness in the Indian pharmaceutical industry, where different imitators line up to reverse engineer and sell their products.

${ }^{11}$ For convenience, I assume that patent protection leads to a perfect monopoly. This does not have to be the case in practice, such as in case of licensing, but it serves to highlight the extreme case.
} 
innovators receive monopoly revenue of $\mathrm{B}_{1} \mathrm{DC}_{2} \mathrm{~B}_{2}$, and the regulation creates a deadweight loss of $\mathrm{DC}_{2} \mathrm{C}_{1}$.

These costs in Phase Two may be worthwhile if the national patent legislation stimulates innovation in Phase Three. Consider two types of innovations according to their degree of ingenuity. A major innovation is represented by the lower-cost supply curve $\mathrm{S}_{2}$ in Figure $3 \mathrm{a}$. If the new cost of production due to innovation is lowered enough that the monopoly price of the new drug is below the Phase One domestic price $P_{d}$, then consumers would gain a surplus of $A_{3} C_{3}$. This is greater than the Phase One consumer surplus $\mathrm{AB}_{1} \mathrm{C}_{1}$, and certainly greater than the Phase Two consumer surplus $\mathrm{AB}_{2} \mathrm{C}_{2}$. If the new innovation is originated by a national, producer surplus of $\mathrm{B}_{3} \mathrm{C}_{3} \mathrm{~EB}_{4}$ is added to the total welfare of the country. Otherwise, monopoly rents go to the foreign inventor and are not captured by the country. In either case, there is a deadweight loss $\mathrm{C}_{3} \mathrm{EC}_{4}$ associated with the monopoly supply. With a small innovation, represented by a higher Phase Three supply curve in Figure 3b, the resulting consumer surplus is greater than that in Phase Two, but less than that in Phase One.

In Phase Four, when the patent expires, the drug invented in Phase Three is widely produced and marketed at price $\mathrm{P}_{\mathrm{d}}^{\prime}$ in Figure $4 \mathrm{a}$ (or $4 \mathrm{~b}$ ). The consumer surplus increases to $\mathrm{AB}_{4} \mathrm{C}_{4}$ (or $\mathrm{AB}_{4}{ }^{\prime} \mathrm{C}_{4}{ }^{\prime}$ ). Compare Phase Four with Phase One: The consumers now enjoy a larger quantity of new drugs at a lower price as a result of the innovation.

As the graphs clearly show, whether or not a country benefits from adopting national patent legislation depends on the dynamic impact of the patent privilege. If the patent legislation stimulates innovation, consumers can realize more surplus in Phase Four. The welfare of the country may even rise as early as Phase Three, depending on the degree of the innovation (how low the new supply curve lies) and the innovation's origin. If the new innovation in Phase Three is originated by a national, then producer surplus of $\mathrm{B}_{3} \mathrm{C}_{3} \mathrm{~EB}_{4}$ is added to the total welfare of the country. If the new innovation is originated by a foreigner, the country could still benefit as long as 
the technology was transferred to the home country at a relatively low cost: for instance, technology transfers via foreign inventors' (frequently employees of MNCs) imparting knowledge and skills to the national employees in the subsidiaries established by the MNCs in a country. Alternatively, the country could acquire the new innovation through licensing or importing. This, however, usually associates with large amount of rents pocketed by the foreign inventor. In the foreign monopoly with no technology-transfer case, the surplus is not captured by the country.

Multi-country theoretical models predict that more national patent protection in developing countries may not add much to $R \& D$ investment incentives, given the high level of patent protection in the developed world (Chin and Grossman 1990, Deardorff 1992, and Helpman 1993). If so, then developing countries are better off without national patent protection, which will allow them to free-ride off innovations generated elsewhere. In the graph, this could be shown as movement directly from Phase One to Four without any potential loss in the other two phases. Notably, this will also shorten the technology diffusion time for the country. The domestic imitators will bring the new innovation into the domestic market at price $\mathrm{P}_{\mathrm{d}}$ ' shortly after the innovation is developed without having to wait until patent expiration (typically 20 years, according to the TRIPS agreement).

The importance of domestic patent protection for pharmaceuticals in developing countries is least controversial in special cases where the targeted diseases are only found in the home country. Consider a therapy for which no medicines are currently available: There is no consumer surplus in the country at all in Phase One. The lack of demand elsewhere makes foreign patent laws irrelevant. Without a national patent system to block imitations, inventors are not likely to invest in developing a new medicine unless through altruism or through government-funded projects. ${ }^{12}$

\footnotetext{
12 Trouiller and Olliaro (1999) provides some figures: “... of the 1,223 new molecular entities sold worldwide during 197596, less than 1\% were destined for tropical diseases." Most of these drugs are generated either from "incidental discoveries in veterinary medicine or from molecules discovered by governmental or academic institutions” (p. 1).
} 
Of course, even a developing country's national patent might not provide enough market incentive for innovators to devote research resources to the country's specific disease. This implies that a group of countries with similar therapeutic needs should implement patent laws together. The Pharmaceutical Research and Manufacturing Association of America (PHARMA) advanced that view during the TRIPS negotiations, and it is formalized mathematically by Diwan and Rodrik (1991). Yet, there is no evidence so far that the research investments or innovations in tropical disease drugs have increased significantly following a group of developing countries implementation of TRIPS-compliant national patent laws (Lanjouw and Cockburn 2000). ${ }^{13}$

The costs of patent implementation for developing countries are clearly identified in the literature. They range from the capture of national patent monopoly rights mainly by foreigners (Lanjouw 1998, Maskus 2000) to the legal administration and litigation costs that a national patent system entails (UNCTAD 1996, Love 2001). At the same time, previous research fails to reach consistent conclusions regarding the innovation gain that countries may derive from the implementation of national patent systems. (Challu [1995], Scherer and Weisburst [1995], and Lanjouw and Cockburn [2000] contrast with Pazderka [1999], the PMPRB 1997] and McFetridge [1996]). The present study controls for national prepatent (Phase One) characteristics that are relevant for patent implementation and innovative potential, and tests whether domestic patent laws have stimulated domestic pharmaceutical innovations and technology transfer, primarily foreign direct investment, in Phase Three.

\section{STUDY AND DESIGN AND DATA}

\footnotetext{
${ }^{13}$ One reason might be that the impacts were not yet felt by the year 2000 , when their research was conducted. I am working on a project to investigate the impacts of TRIPS-compliant, national patent laws on various disease categories.
} 
Had national patent systems been implemented as exogenous shocks, the effects of patent protection on innovation and technology transfers could be tested simply by comparison of mean innovation and FDI levels between the patent and non-patent countries. This ideal randomization faces severe practical limitations. In fact, individual countries make the decisions whether to have national patent laws. The country characteristics may affect the innovation, FDI, and trade outcomes, as well as the decision of national patent implementation. Qian (2007) and this companion study apply a statistical matching method to form country pairs where patent treatment can be considered randomly assigned within each pair. Limited space does not permit full discussion here; please see Qian (2007) for details. I define treatment as the implementation of new, national pharmaceutical patent law, and control as no change of patent law. A dummy variable "PAT" is constructed to indicate the patent treatment. Two control groups ("PAT" =0) are defined in order to make the most use of the sample size available, and to check the robustness of results. One control group consists of countries that never had patent protection for pharmaceuticals up until the reference period, and the other control group consists of countries that had patent protection even before the reference period. The treated group ("PAT" = 1) consists of the countries that implemented new pharmaceutical patent laws during the reference period. Table 1 lists the specific years the sampled countries started to implement new pharmaceutical patent protection.

Most of the new-patent countries had some degree of protection for pharmaceutical processes before they formally introduced national patents for pharmaceutical products in the corresponding periods. The only exceptions are Brazil, China, Chile, Korea, Indonesia, Mexico, Peru, Romania, Taiwan, Thailand, and Turkey. ${ }^{14}$ An indicator variable "PATMOD" is constructed to distinguish countries that started implementing pharmaceutical patent law anew $(\mathrm{PATMOD}=0)$

\footnotetext{
14 This information is obtained by cross-referencing Lerner (2000) Table 1, his listed source documents, and the WIPO (1992) document.
} 
from those that modified their patent laws to protect pharmaceutical products as well as processes $(\mathrm{PATMOD}=1)$

The study design called for an extensive effort to gather suitable data, and Qian (2007) collected data from various international databases and different countries' Yearbooks. This companion study gathered more U.K. FDI data and international trade data to merge with the original database in order to test the impacts of patent laws on technology transfers. ${ }^{15}$ However, because the other FDI data I have are the number of U.S. and Japanese FDI subsidiaries in each country, they are not compatible with the U.K. data. I have to carry out analyses on them separately and sum the U.S. and Japanese FDI establishments to test the patenting effects on aggregated FDI. As will be discussed in detail later, the results across various specifications are robust. The dataset described in Qian (2007) already includes trade data from the World Trade Analyzer by Statistics Canada. I now obtain the total pharmaceutical imports each country purchased annually worldwide from the new NBER database by Feenstra and Lipsey (2005). I transform some of the variables logarithmically.

\section{METHODOLOGY}

The same two-stage procedure as proposed by Qian (2007) is executed in this study. Please refer to Qian (2007) for the methodology details and the list of matched countries. The formal regression model is estimated on the two groups of matched pairs (Set 1: non-patent and newpatent pairs; and Set 2: always-patent and new-patent pairs) separately:

$$
\begin{gathered}
\operatorname{RESPONSE}_{i j(t+n)}=\beta_{0}+\beta_{1} * \mathrm{PAT}_{i j}+\beta_{2} * \mathrm{PATMOD}_{i j}+\beta_{3} * \operatorname{INTERACT}_{i j}+\beta_{4} * \\
\text { COVARIATES }_{i j}+\beta_{5} * \mathrm{D}_{t}+\beta_{6} * \operatorname{RESPONSE}_{i j t}+\varepsilon_{i}(1)
\end{gathered}
$$

\footnotetext{
${ }^{15}$ I obtained the amount of FDI the U.K. poured into different countries in the sampled period from the various U.K. Yearbooks. Only the FDI host countries that are listed in the Yearbooks were included.
} 
Where " $\beta_{0}$ " consists of the pair specific-effects. That is, $\beta_{0}=\alpha_{1} * D_{1}+\alpha_{2} * D_{2}+\ldots+\alpha_{m} * D_{m}=$ $\sum_{j=1}{ }^{m} \alpha_{j} * D_{j} . \quad D_{j}$ is the indicator variable for pair $j$, which takes on value 1 if the observation belongs to pair $j$, and 0 otherwise. "PAT $i j$ " is the dummy indicator of whether the country $j$ in pair $i$ changed pharmaceutical product patent laws or not. ${ }^{16}$ All the countries in the control group (that have not experienced law change during the period under examination) had process patents. "RESPONSE $i j(t+n)$ " is the outcome variable of each country $j$ of pair $i$ in the reduced sample in period (or year) $t+n$ ( $n$ years after patent implementation). A similar definition applies to "RESPONSE $\mathrm{ijt}$ " for period (or year) $t$. In Qian (2007), the outcome variable is the increase in the U.S. patent awards after the new patent implementation, the R\&D expenditure in pharmaceuticals, and the pharmaceutical exports, respectively, in separate specifications. In this companion study, I use the FDI measures (from the U.S., Japan, and the U.K., first separately, and then the sum of U.S. and Japanese subsidiaries) as the outcome variable. When testing the impacts of patents on imports, I specify the outcome to be the total value of pharmaceutical imports of each country in the year of examination.

" $\mathrm{D}_{t}$ " stands for the five dummy variables for each of the periods. (e.g., $\mathrm{D}_{t}$ takes on value 1 if pair $i$ is matched when examining the period 1978-83, and the other four period dummies for pair $i$ have value 0.) "PAT" and "PATMOD" are as defined in Section 3 (also see the Data Appendix). "INTERACT" and control variables are specified in Qian (2007). The regression residual is denoted by $\varepsilon_{i \text {. }}$

\section{RESULTS}

\section{A. Patenting Effects on Innovations — Summarizing Results from Qian (2007)}

\footnotetext{
${ }^{16}$ Pharmaceutical-patent laws are quite separate from other patent laws. Empirically, the probability that a country has a change in drug patents at the same time as other areas is less than 5\%. This study is of pharmaceutical patents, not patents generally, and one does not necessarily suggest anything regarding the other.
} 
The citation-weighted U.S. patent awards and pharmaceutical exports can be considered estimates of innovation outputs, while $R \& D$ expenditures provide an estimate of innovation inputs. Different regression specifications yield the same result: There is insufficient statistical evidence to conclude that pharmaceutical-patent implementation by itself has generally stimulated R\&D incentives.

Although national patent laws alone were not found to stimulate domestic innovations, Qian (2007) discovers some conditional importance of the pharmaceutical-patent implementations. In particular, a more developed country with pharmaceutical patents is likely to have more R\&D incentive compared to a similarly developed country without patents, or a less developed country with patents. Similarly, patent-law implementations are associated with higher levels of domestic innovations in countries with higher educational attainment or economic freedom.

It is interesting to note that the positive interaction effect of patent policy and the economic freedom index are especially pronounced in the OECD subsample. Qian (2007) suggests the possibility that in a highly integrated market, as that formed by the OECD countries, the national patent law could complement a member country's open-market access and favorable domestic investment policies to attract FDI and other forms of foreign-technology transfers. The results presented in the next section lend support to this explanation. National patent laws could also help domestic companies in assimilating these inbound technology transfers through patent disclosures. Economic freedom can also help countries with new patent systems leverage their emerging national intellectual property advantages by facilitating exports. Qian (2007) additionally analyzed the patenting effects on the R\&D scientists, technicians and engineers (RSE) for the 10 OECD countries whose data on pharmaceutical RSE are available, and the results corroborate those on R\&D expenditures.

Qian (2007) provides empirical evidence that the relationship between patent strength and innovation adopts an "inverted U" shape. Most OECD countries had pharmaceutical process 
patents before they introduced product patents; it is likely that a country's process innovations were effectively protected if its initial national IPR protection is strong. Additional product patents, then, may not stimulate innovation, as Scherer (1977) and Kumar (1996) also seem to suggest. ${ }^{17}$ In fact, the strengthening of patent protection may block domestic initiatives to engage in "imitative" innovations, while "ingenious" innovation may not come easily and quickly. This leads to an overall decline in domestic R\&D activities in the short run. Figure 1 in Qian (2007) provides a visual check of the innovation trends across countries of different IPR strengths.

As a side note, Qian (2007) provides some evidence for a negative association between a country's price-control policy and its innovation outcomes. The interaction variable between pharmaceutical patent law and price-control policy also takes a negative coefficient. This finding is in agreement with others' (Grabowski and Vernon 1992, Danzon 1996) that price-control policy tends to impair domestic innovation, evinced by the fewer patents obtained in the U.S. and less R\&D.

\section{B. PATENTING EFFECTS ON FDI}

Table 2 lists the regression estimates of the patenting effects on FDI, as measured with the sum of the pharmaceutical FDI establishments by U.S. and Japanese subsidiaries in the home country where a national pharmaceutical-patent law was newly implemented. The statistically insignificant coefficients on the patent-implementation variable again exhibit null effects when patent policy alone is switched. However, patent implementation in combination with a freer economy and with reasonable human capital in the host country does seem to attract FDI

\footnotetext{
${ }^{17}$ Scherer (1977) finds no clear relationship between the strength of intellectual property protection and the number of new drugs introduced per dollar of GDP (p. 39). Among his pieces of evidence is the fact that Switzerland and Denmark had the highest new drug-to-GDP ratio during 1940-75, when they protected only pharmaceutical processes. The U.S. and Belgium, where both processes and products are protected, ranked third and fourth. Italy ranked 13th, although it had no pharmaceutical protection then. Canada only protected processes and had compulsory licensing during 1969-75, and ranked 15th (p. 38). Scherer's result is corroborated in Kumar (1996) for the food and chemicals industries. Kumar finds that the R\&D intensity of majority-owned affiliates of U.S. multinationals is no higher in countries that grant both product and process patents than it is in countries where only process patents are granted.
} 
establishments, evinced by the significantly positive coefficients on the interaction variables. (The patent-implementation dummy interacted with the economic-freedom index and with education attainment - see columns 3 and 5 in Table 2, respectively.) This empirically confirms the conjecture in Qian (2007) that the national patent law could complement a member country's openmarket access and favorable domestic investment policies to attract FDI. Branstetter et al. (2006) additionally finds positive impacts of IPR reforms on FDI by using a unique and confidential dataset from the Bureau of Economic Analyses. Their data on FDI is admittedly better than the establishment data I have because the detailed, firm-level data enable them to see royalty payments from U.S. MNCs to subsidiaries in various countries. Patent reforms could have stimulated R\&D expenditures and transfers in the MNCs subsidiaries in the host countries, even if the number of FDI subsidiaries did not increase.

Education levels are predicted to be positively correlated with FDIs, statistically significant at the 5\% level. This speaks to the strong attraction of human capital for FDI. CEOs of several top, international companies (e.g., GE, P\&G, and Unilever) recently stated on Chinese television that they had established multiple subsidiaries in China more to benefit from China's wealth of talented, innovative people than to save on labor costs. It is perhaps not coincidental that MNCs' research laboratories have proliferated in countries like China and India as these countries have developed and improved their national-education attainments.

I used FDI in two, three, and up to six years after national patent implementation as alternative response-variable specifications, and the results remain robust. The gist of the findings also did not change when I analyzed the U.S. and Japanese FDI establishments, and U.K. FDI expenditures separately. 


\section{PATENTING EFFECTS ON IMPORTS}

As displayed in columns 6 and 7 of Table 2, the sampled countries absorbed more pharmaceutical imports after the implementation of national pharmaceutical-patent laws for the first time. This hints at the possibility that foreign producers are more willing to sell their products to these countries knowing that the new patent laws will guard against imitations in these importer countries.

The welfare implications of import increases are harder to fathom from the data at hand. On the one hand, imports are sometimes considered a channel of technology transfer because the imports are products that importers lack or need, and importers can learn from reverse engineering them. Even if the new patent laws prohibit copycats, the laws certainly do not prohibit making use of imported equipments or learning from imported products. On the other hand, the increase in imports and insignificant change in exports in the pharmaceutical industry post patent reforms could imply a deterioration of terms of trade, a finding that was also concluded in the Italian IP study by Scherer and Weisburst (1995).

A country's purchasing power, openness, and pharmaceutical-industry size are naturally positively correlated with the import values as well, reflected by the positive and significant coefficients on the GDP per capita PPP, economic freedom, and pharmaceutical-industry employment variables.

\section{DISCUSSIONS}

The empirical findings that national patent protection alone does not lead to a positive jump in innovation, as estimated by U.S. patent awards, R\&D expenditure, and pharmaceutical exports, is hardly surprising. Some developing countries have always had patent protection, yet, domestically, they do not have innovative potential and rely heavily on imports. For instance, 
patent-application data from the EPO and awards data from the USPTO show that French West Africa never applied for or obtained any pharmaceutical patent from these two offices during 19782000, despite its well-established national patent laws. Reports reveal that the top $10 \mathrm{MNCs}$ control $35 \%$ of the $\$ 297$ billion in gross sales of the global pharmaceuticals industry generated in 1998 (Human Development Report 1999). These top companies are responsible for the major pharmaceutical innovations. The top 27 pharmaceutical companies ranked by $R \& D$ spending in U.S. dollars for 1998 are mostly concentrated in Britain, Germany, Japan, Switzerland, and the U.S. (Industrial Research Institute 2000).

It is also possible that the lack of a statistically significant increase in the U.S. patent awards and FDI after national patent legislation is linked to data limitations, most of which are discussed in detail in Qian (2007) and Section 5.2. In addition, the pharmaceutical industry-level FDI data I am able to obtain are limited to those from the U.S., Japan, and U.K. To the extent that these three countries' FDI expenditures are the major components of total FDI from North America, Asia, and Europe, and under the assumption that the changing pattern of FDI from other nationalities most likely parallels that of the data at hand, the results presented here at least provide a glimpse of the patenting effects on FDI. We do need to be careful not to over-generalize the findings, especially in light of research findings elsewhere that support a positive relationship between patenting and FDI using other datasets (Branstetter et al. 2006).

Concerns regarding institutional details may also have slowed down the impacts of national patent implementations. The TRIPS agreements were not reached until the final moments of the Uruguay Round negotiation, and innovators may have been uncertain about the future of patent protection. The aforementioned difficulty faced by developing countries in training legal personnel and enforcing their domestic patent laws can also add to innovators' hesitation to engage in R\&D activities there. UNCTAD (1996) estimates the administrative compliance costs with TRIPS agreements for a number of developing countries to far exceed U.S. \$1 million. Patent 
implementation may, in fact, divert the resources that could have been employed in R\&D activities. Even with a reported median cost of U.S. patent litigation of $\$ 1.2$ million per side (New York Times, December 27, 1998), the quality of U.S. patent examination is not ensured. "According to a study by Lemley and Allison, of patents litigated to judgment [between 1989 and 1996], 54\% were found to be valid and $46 \%$ invalid" (Love 2001). The technical know-how required of legal personnel is an unrealistic expectation for developing countries at this stage, and its lack could lead to misjudgments with serious impacts on the domestic market. For example, Bristol-Myers Squibb (BMS), an American drug company, was able to obtain patents for formulation claims of DDL, a drug for HIV/AIDS, in Thailand even though BMS is not the inventor of DDL. BMS used this patent to block generic DDL pill production in Thailand (Love 2001). If innovators doubt that the domestic legal system could make good judgments, the incentives to innovate, or to extend FDI and technology transfers, could be dampened.

Patent laws may affect innovation in dimensions other than raising its absolute number, in particular, changing the direction of innovative activity (Moser 2003). Nevertheless, the findings in Qian (2007) and this companion piece have important policy implications. They vindicate Maskus' (2000) argument that "expectations that stronger IPRs alone will bring technical change and growth are likely to be frustrated" (p. 199). Countries with different degrees of development, general intellectual property strength, and economic freedom have varying innovative responses to changes in national patent law, as evidenced in the domestic pharmaceutical R\&D levels and the number of drug patents obtained in the U.S. Most of these country characteristics indeed go hand in hand with each other. Kumar (1996) finds a positive relationship between the R\&D intensity of U.S. affiliates and the strength of the country's intellectual property rights — in developed countries, but not in developing ones.

In that vein, many developed countries, including U.K., Germany, and Switzerland, had opposed national patent legislation when they were technology importers (Chang 2001). These 
countries took advantage of the freely accessible foreign technologies during their industrialization process. Evenson (1990) argues that countries have no interest in strong intellectual property rights until they become significant technology exporters. WTO advocates may argue that the TRIPS agreements already allow for adjustment time, since developing countries had a grace period of five years and the least-developed countries had 10 years. However, it is unlikely to see developing countries transform from mere "technology importers" to even moderate "technology exporters" within this short timeframe. 7 KHHIDHMJ QIIFDQMSRMQWOEHQHLWMRIP SLRYQ IFRXQNHMRYHDO GHHRSP HQWkevels, establishing solid technological infrastructure, and lubricating market

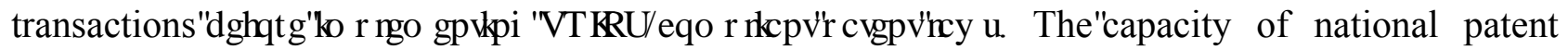
protection to stimulate domestic innovations and inbound technology transfers appears to be contingent on these other factors.

Furthermore, it may be important for developing countries to have a discriminatory national patent system to help domestic companies flatten their learning curves and gradually learn to innovate. According to the welfare analyses in Section 2, national patenting could bring welfare gains to a country if innovation is stimulated, and, particularly, if the innovation is originated by nationals. Previous research shows that, in many cases, domestic patent law mainly benefits foreign innovators, since producer surplus is captured mostly by foreigners (Lanjouw 1998, and McFetridge 1996). Therefore, it might generally be in developing countries' interests to grant patents only to nationals and not to foreigners.

Granted, if patent laws in developing countries could help stimulate innovations that target nation- or region-specific, diseases, then the optimal strategy for the developing countries might be to grant patents to all innovators, including nationals and foreigners. But this would apply only for the region-specific underdeveloped drugs in question. After all, why not tackle the source of the problem by targeting just the drugs that are most urgently in need of development? 
Though economically sound, these discriminatory policies are unlikely to be implemented due to the WTO norms of non-discrimination and reciprocity. To borrow Schiff's (1971) phrase in this context regarding the desirability and feasibility of a unilateral discriminatory patent policy, "economically, the answer is yes ... [but] politically, the answer is no" (p. 26). It is perhaps an encouraging sign that the recent Doha Act resulting from WIPO negotiations acknowledges individual needs of different countries, although the Doha Declaration and Article31bis added to TRIPS to reflect the Declaration, are far more limited than is suggested here.

\section{CONCLUSIONS}

After controlling for a list of country- and industry-level variables that are likely to affect innovative potentials and technology transfer, there is no statistically significant relationship between national pharmaceutical-patent protection and innovation or FDI establishments. However, the interactions of national patent-law implementation with development level, educational attainment, and economic freedom, respectively, are shown to have a positive relationship with the domestic $\mathrm{R} \& \mathrm{D}$ expenditure and domestic pharmaceutical-patent awards in the U.S. after national patent implementation. Furthermore, there appears to be an optimal level of intellectual property rights regulation, above which further enhancement of protection is actually associated with a decline in innovative activities in developed, as well as developing, countries (Qian 2007). National patent protections in combination with economic freedom and higher education level are also positively related to increases in U.S. and Japanese MNC subsidiaries and British FDI. Imports increased with unclear welfare implications. In short, for countries that have relatively low levels of development and market freedom, the net domestic welfare change due to patent protection is clear: Rent transfers to foreigners immediately follow the national patent 
legislation (Figure 2), while any benefits from additional innovation depend ultimately on the country's macroeconomic factors and require a substantial time-discount (Figure 3a and b).

Although this study yields interesting results, more research should follow on this topic. Qian (2006) examines the IPR enforcements and the impacts of counterfeits, the flipside of IPR. Rigorous investigation of the impacts of TRIPS-compliance patent-law implementations on the global incentives to innovate new drugs for different disease types and on developing countries' access to drugs are all important questions to address.

\section{REFERENCES}

Bessen, James, and Eric Manskin. 2000. Sequential Innovation, Patents, and Imitation. Working Paper No. 00-01, Department of Economics, Massachusetts Institute of Technology.

Branstetter, Lee, Raymond Fisman, and Fritz Foley. 2006. "Do Stronger Intellectual Property Rights Increase International Technology Transfer?"

Quarterly Journal of Economics 121:1, 321-349.

Cadot, Olivier, and Steven Lippman. 1995. Barriers to Imitation and the Incentive to Innovate.

Working Paper No. 434, Western Management Science Institute; University of California, Los Angeles.

Challu, Pablo, M. 1995. Effects of Monopolistic Patenting of Medicine in Italy Since 1978. International Journal of Technology Management 10, pp.237-51. 
Chin, Judith, and Grossman, Gene. 1990. Intellectual Property Rights and North-South Trade. In Ronald W. Jones, and Anne O. Krueger, eds. The Political Economy of International Trade: Essays in Honor of Robert E. Baldwin. Cambridge, Mass.: Basil Blackwell, pp.90-107.

Cochran, W.G., and Chambers, S. Paul. 1965. The Planning of Observational Studies of Human Populations. Journal of the Royal Statistical Society. Series A (General), Vol. 128, No. 2.:234-66.

Danzon, Patricia. 1997. Pharmaceutical Price Regulation. Washington D.C.: American Enterprise Institute.

Deardorff, Alan. 1992. Welfare Effects of Global Patent Protection. Economeica, 59: 36-51.

Diwan, Isaac, and Dani Rodrik. 1991. Patents, Appropriate Technology, and North-South Trade. Journal of International Economics, 30: 27-48.

Evenson, Robert E. 1990. Survey of Empirical Studies. In Wolfgang E. Siebeck, ed. Strengthening Protection of Intellectual Property in Developing Countries: A Survey of the Literature.

Washington, D.C.: The World Bank Discussion Paper No.112

Evenson, Robert E. 1990a. Intellectual Property Rights, R\&D, Inventions, Technology Purchase. In Robert E. Evenson, and Gustav Ranis, eds. Science and Technology: Lessons for Development Policy. Boulder, Colorado: Westview Press, pp. 325-55. 
Evenson, Robert E. 1990a. Piracy in Economic Development: An International Comparative Study. In Robert E. Evenson, and Gustav Ranis, eds. Science and Technology: Lessons for Development Policy. Boulder, Colorado: Westview Press, pp. 325-55.

Feenstra, R.C., R.E. Lipsey, H. Deng, A.C. Ma, H. Mo. 2005. World Trade Flows: 1962-2000. NBER Working Paper 11040.

Gallini, Nancy. 1992. Patent Policy and Costly Imitation. Rand Journal of Economics, 23: 52-63.

Gnanadesikan, R. 1977. Methods for Statistical Data Analysis of Multivariate Observations. Second Edition. New York: John Wiley \& Sons, Inc.

Grabowski, Henry G., John M. Vernon. October 1992. Brand Loyalty, Entry, and Price Competition in Pharmaceuticals after the 1984 Drug Act. Journal of Law \& Economics. Vol. 35 (2). p. 331-50.

Griliches, Zvi. 1984. R\&D, Patents, and Productivity. Chicago: The University of Chicago Press.

Ha-Joon, Chang. 2001. Intellectual Property Rights and Economic Development — Historical Lessons and Emerging Issues. In United Nations Development Programme, ed. Human Development Report Background Papers. New York: Human Development Report Office.

Harabi, Najib. 1997. Appropriability of technical innovations: An empirical analysis. Research Policy 24 (6): 981-992. 
Heckman, J.J., H. Ichimura, J. Simith, and P. Todd. 1996. Sources of Selection Bias in Evaluating

Social Programs: An Interpretation of Conventional Measures and Evidence on the Effectiveness of Matching as a Program Evaluation Method. Proceeding of the National Academy of Sciences of the United States of America, Vol. 93, pp.13416-20.

Helpman, Elhanan. 1993. Innovation, Imitation, and Intellectual Property Rights. Econometrica, 61: 1247-80.

Industrial Research Institute, Inc. 2000. R\&D Spending Patterns of Global Firms: Part 1 of 7. Research Technology Management, 43 (5): 40-56, September 2000.

Jaffe, Adam. 2000. The U.S. Patent System in Transition: Policy Innovation and the Innovation Process. Research Policy, 29: 531-57.

Jaffe, Adam, and Josh Lerner. 2004. Innovation and Its Discontents: How Our Broken Patent System Is Engandering Innovation and Progress and What to Do About It. New Jersey: Princeton University Press.

Kaufer, Erich. 1989. The Economics of the Patent System. U.K.: Harwood Academic Publishers.

Kortum, Samuel, and Josh Lerner. 1998. Stronger Protection or Technological Revolution: What is Behind the Recent Surge in Patenting? Carnegie-Rochester Conference Series on Public Policy, 48: 247-304. 
Kumar, Nagesh. 1996. Intellectual Property Protection, Market Orientation and Location of Overseas R\&D Activities by Multinational Enterprises. World development 24, pp.673-88.

Lanjouw, Jean, and Iain Cockburn. 2000. Do Patents Matter? Empirical Evidence After GATT. NBER Working Paper W7495.

Lanjouw, Jean. 1998. The Introduction of Pharmaceutical Product Patents in India: Heartless Exploitation of the Poor and Suffering? NBER Working Paper W6366.

Lanjouw, J., A. Pakes, and J. Putnam. 1996. How to Count Patents and Value Intellectual Property: Uses of Patent Renewal and Application Data. NBER Working Paper W5741.

Lerner, Josh. 2000. 150 Years of Patent Office Practice. NBER Working Paper W7477.

Lerner, Josh. 2000a. 150 Years of Patent Protection. NBER Working Paper W7478.

Levin, Richard, Alvin Klevorick, Richard Nelson, and Sidney Winter. 1987. Appropriating the Returns from Industrial Research and Development. Brookings Papers on Economic Activity, 3:783-820.

Love, James. 2001. Access to Medicine and Compliance with the WTO TRIPS Accord: Models for State Practice in Developing Countries. Paper for the United Nations Development Programme Consumer Project on Technology. Available online at: http://www.cptech.org

Mansfield, Edwin, Mark Schwartz, and Samuel Wagner. 1981. Imitation Costs and Patents: An 
Empirical Study. The Economic Journal, 91: 907-18, December 1981.

Maskus, K. 1998. The International Regulation of Intellectual Property. Weltwirtschaftliches Archiv, 134: 186-208.

Maskus Keith. 2000. Intellectual Property Rights in the Global Economy. Washington, D.C.: Institute for International Economics.

Maskus, K., and D. Eby-Konan. 1994. Trade-Related Intellectual Property Rights: Issues and Exploratory Results. In Alan Deardorff, and Robert M. Stern, eds. Analytical and Negotiating Issues in the Global Trading System. Ann Arbor, Mich.: University of Michigan Press.

Maskus, K., and M. Penubarti. 1995. How Trade-Related Are Intellectual Property Rights? Journal of International Economics, 39: 227-48.

McFetridge, Donald G. 1996. Intellectual Property, Technology Diffusion and Growth. Mimeo. Ottawa: Carleton University.

Moser, Petra. 2003. How Do Patent Laws Influence Innovation? Evidence from NineteenthCentury World Fairs. NBER Working Paper 9909.

Nelson, Richard R. 1990. On Technological Capabilities and Their Acquisition. In Robert E. Evenson, and Gustav Ranis, eds. Science and Technology: Lessons for Development Policy. Boulder, Colorado: Westview Press, pp. 71-80. 
Park, Walter G. 2000. International Patenting, Patent Rights, and Technology Gaps. American University Manuscript, March 2000.

Patented Medicines Prices Review Board. 1997. A Comparison of Pharmaceutical Research and Development Spending in Selected Countries. Paper presented at the Canadian Economics Association Annual Meetings, St. John's, Newfoundland, June 6-8.

Pazderka, Bohumir. 1999. Patent Protection and Pharmaceutical R\&D Spending in Canada. Canadian Public Policy, 25, No. 1: 29-46.

Qian, Yi. 2006. Impacts of Entry by Counterfeiters. Harvard University Working Paper. (Under review at the Quarterly Journal of Economics.)

Qian, Yi. 2007. Do National Patent Laws Stimulate Domestic Innovation In A Global Patenting Environment? - A Cross-Country Analysis of Pharmaceutical Patent Protection: 1978-2002. Review of Economics and Statistics Vol. 89, issue 3: pp. 436-453. Cambridge, Mass.: MIT Press. Sakakibara, Mariko, and Branstetter, Lee. 1999. Do Stronger Patents Induce More Innovation? Evidence from the 1988 Japanese Patent Law Reforms. NBER Working Paper 7066.

Scherer, F.M. 1977. The Economic Effects of Compulsory Patent Licensing. New York: New York University Graduate School for Business Administration.

Scherer, F.M., and Jayashree Watal. 2000. Post-TRIPS Options for Access to Patented Medicines in Developing Countries. Center of International Development Manuscript, December 2000. 
Scherer, F.M., and S. Weisburst. 1995. Economic Effects of Strengthening Pharmaceutical Patent Protection in Italy. International Review of Industrial Property and Copyright Law 26:1009-24.

Schiff, Eric. 1971. Industrialization without National Patents. New Jersey: Princeton University Press.

Scotchmer, Suzanne, and Jerry Green. 1990. Novelty and Disclosure in Patent Law. Rand Journal of Economics, 21: 131-46.

Schumpeter, Joseph. 1942. Capitalism, Socialism, and Democracy. New York: Harper \& Brothers Publishers.

Siebeck, Wolfgang E., ed., with Robert E. Evenson, William Lessor, and Carlos A. Primo Braga. 1990. Strengthening Protection of Intellectual Property in Developing Countries: A Survey of the Literature.Washington, D.C.: World Bank Discussion Papers No. 112.

Smith, Pamela J. 1999. Are Weak Patent Rights a Barrier to U.S. Exports? Journal of International Economics, 48: 151-77.

Smith, P. 2001. How Do Foreign Patent Rights Affect U.S. Exports, Affiliate Sales, and Licenses? Journal of International Economics, 55: 411-439.

Subramanian, Arvind. 1991. The International Economics of Intellectual Property Right Protection: A Welfare-Theoretic Trade Policy Analysis. World Development, 19, No. 8: 945-56. 
Taggart, James. 1993. The World Pharmaceutical Industry. London and New York: Routledge.

Taylor, C., and Z. Silberston. 1973. The Economic Impact of the Patent System. Cambridge: Cambridge University Press.

Trouiller, Patrice, and Piero Olliaro. 1999. Drug Development Output: What Proportion for Tropical Diseases? The Lancet, 354, July 10.

UNCTAD. 1996. The TRIPs Agreement and Developing Countries. Geneva: United Nations Conference on Trade and Development.

United Nations Development Programme. 1999. Human Development Report. New York and Oxford: Oxford University Press.

Yang, G., and K. Maskus. 2001. Intellectual Property Rights and Licensing: An Econometric Investigation. Weltwirtschaftliches Archiv, 137: 58-79. 


\section{APPENDIX}

Fig 1. Phase One: Before national patent legislation Fig 2. Phase Two: Immediate consequence of patent law

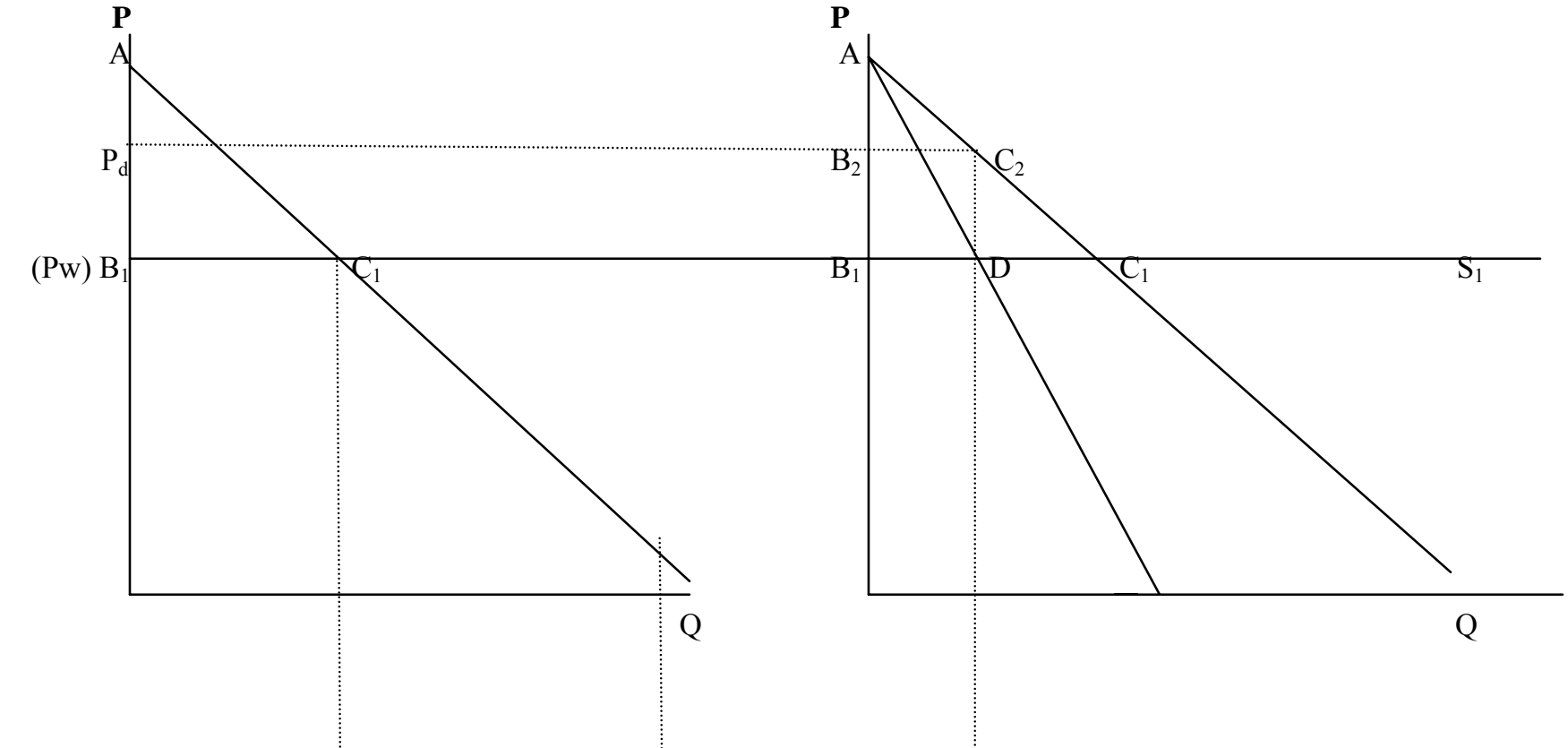

Fig 3a. Phase Four: After a patent expires Fig 4a. Phase Three: Dynamic impact of patent law: major innovation

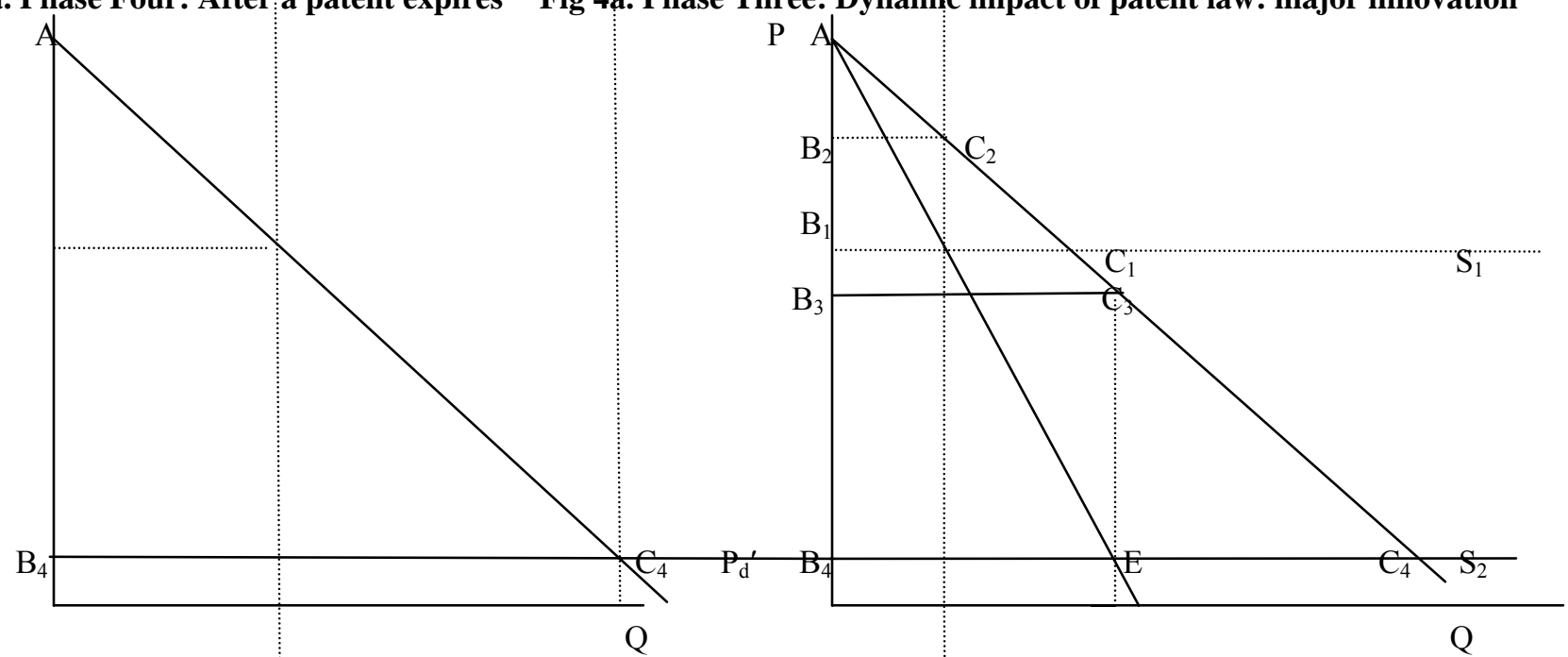

Fig 3b. Phase Four: After a patent expires

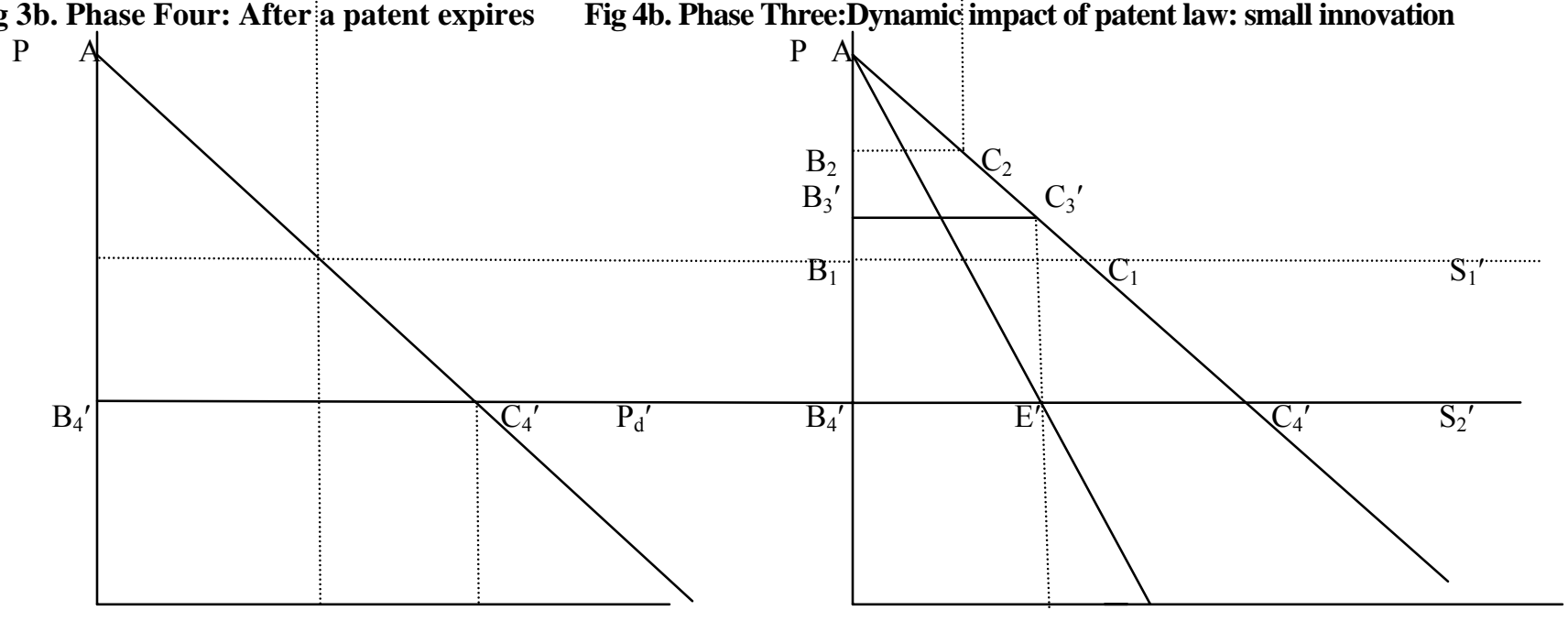


Table 1. Timelines of National Patent Implementations

\begin{tabular}{|c|c|}
\hline Year of patent laws & New-patent countries \\
\hline Period 1 & (1978-82) \\
\hline 1983 & Denmark \\
\hline Period 2 & (1983-85) \\
\hline 1986 & Taiwan \\
\hline 1987 & Canada \\
\hline 1986 & Korea \\
\hline 1987 & Austria \\
\hline Period 3 & $(1986-90)$ \\
\hline 1993 & Brazil \\
\hline 1991 & Chile \\
\hline 1991 & China \\
\hline 1992 & Spain \\
\hline 1995 & Finland \\
\hline 1992 & Greece \\
\hline 1992 & Hungary \\
\hline 1992-1993 & Indonesia \\
\hline 1991 & Mexico \\
\hline 1992 & Norway \\
\hline 1992 & Portugal \\
\hline 1992-1993 & Thailand \\
\hline Period 4 & (1991-95) \\
\hline 1996 & Bolivia \\
\hline 1996 & Colombia \\
\hline 1997 & Ghana \\
\hline 1996 & Iceland \\
\hline 1996 & Peru \\
\hline 1996 or 1997 & Turkey \\
\hline 1997 & Romania \\
\hline 1996 & Ecuador \\
\hline 1996 & Venezuala \\
\hline
\end{tabular}




\section{Table 2. Impacts of National Patent Laws on Log FDI and Import Values.}

Regression results from different regression specifications are tabulated in different columns. The dependent variable of each specification is listed in each column header. FDI is the sum of all the pharmaceutical FDI from U.S. and Japanese establishments in the year of specification. Total import values of a country are from the NBER Trade Database (Feenstra et al. 2001). The PAT Implementation dummy equals one in the years starting from domestic patent implementation identified in Table 1. The PATMOD dummy equals one if the country had pharmaceutical-process patents prior to patent implementation, as listed in section III. Macro data are obtained from World Trade Analyzer, WDI, and UNIDO Industrial Property Statistics. The economic-freedom index comes from the Fraser Institute, legal families from La Porta et al. (1996), and the education proxy from Barro and Lee (2000). The price-control dummy equals one if a country has a pharmaceutical price-control policy and is drawn from Danzon (1997) and Economic Intelligence Unit Reports. The numbers of subsidiaries of U.S. and Japanese MNE are provided by Prof. Fritz Foley and Paul Beamish. I constructed the "innovative potential" categorical variable using the data from the USPTO. It equals 6 if the U.S. patent awards (in all industries except the pharmaceuticals in a year) surpass 1000, 5 if patent count is $<1000$ but $>100,4$ if it is $<100$ but $>6,3$ if it is $<6$ and $>1$, and 1 if there are no patent awards. "PAT * $\mathrm{X}$ " refers to the interaction variable of PAT dummy and the covariate $\mathrm{X}$, where $\mathrm{X}$ is the log of GDP per capita PPP, economicfreedom index, education, or IPR index, or the price-control dummy. Heteroskedasticity-consistent standard errors that correct for clustering at the pair level appear in parentheses.

\begin{tabular}{|c|c|c|c|c|c|c|}
\hline \multirow[b]{2}{*}{ Covariates } & \multicolumn{4}{|c|}{$\begin{array}{c}\text { Dependent Variable: } \\
\text { Log FDI, forwarded by } 1 \text { year }\end{array}$} & \multicolumn{2}{|c|}{$\begin{array}{l}\text { Dep.Var.: } \log \text { Imports, } \\
\text { forwarded by } 1 \text { year }\end{array}$} \\
\hline & No-paten & $\begin{array}{l}\text { ew-patent } \\
\text { es }\end{array}$ & $\begin{array}{l}\text { Always-pa } \\
\text { patent Cot }\end{array}$ & d New- & $\begin{array}{l}\text { No-patent } \\
\text { and New- }\end{array}$ & $\begin{array}{l}\text { Always- } \\
\text { patent and }\end{array}$ \\
\hline PAT Implementation & $\begin{array}{c}.01 \\
(.92)\end{array}$ & $\begin{array}{c}.33 \\
(.23)\end{array}$ & $\begin{array}{l}-.03 \\
(.11)\end{array}$ & $\begin{array}{c}.31 \\
(.18)\end{array}$ & $\begin{array}{l}.80 * * \\
(.40)\end{array}$ & $\begin{array}{l}.95^{* *} \\
(.30)\end{array}$ \\
\hline $\mathrm{PAT}^{*} \log$ GDPpcPPP & & $\begin{array}{c}.20 \\
(.60)\end{array}$ & & $\begin{array}{c}.68 \\
(.69)\end{array}$ & & \\
\hline $\mathrm{PAT}^{*} \log$ Freedom & & $\begin{array}{c}2.19 * * \\
(.79)\end{array}$ & & $\begin{array}{l}2.93^{* *} \\
(1.06)\end{array}$ & & \\
\hline $\mathrm{PAT}^{*} \log$ Education & & $\begin{array}{l}.42 * \\
(.22)\end{array}$ & & $\begin{array}{l}.62 * * \\
(.29)\end{array}$ & & \\
\hline $\mathrm{PAT}^{*} \log$ IPR score & & $\begin{array}{l}1.35^{*} \\
(.75)\end{array}$ & & $\begin{array}{l}.30 \\
(.36)\end{array}$ & & \\
\hline PAT*Price Control & & $\begin{array}{l}.73 \\
(.98)\end{array}$ & & $\begin{array}{l}.13 \\
(.47)\end{array}$ & & \\
\hline Log GDP per capita & .46 & .69 & .24 & .10 & $1.08^{* * *}$ & $1.74^{* * *}$ \\
\hline PPP & $(1.27)$ & $(1.33)$ & $(.62)$ & $(.64)$ & $(.45)$ & $(.36)$ \\
\hline Log Economic & $6.45 * *$ & $1.28 *$ & $1.45^{* *}$ & .11 & .44 & .39 \\
\hline
\end{tabular}




\begin{tabular}{lcccccc}
\hline Freedom & $(2.39)$ & $(.67)$ & $(.38)$ & $(.32)$ & $(1.00)$ & $(.78)$ \\
Log Education & $1.57^{* *}$ & 2.90 & $1.59^{*}$ & $3.21^{* *}$ & 1.58 & .17 \\
& $(.78)$ & $(2.74)$ & $(.91)$ & $(1.32)$ & $(.85)$ & $(.77)$ \\
Log IPR Score & 2.15 & -.79 & -.57 & -1.25 & .69 & -.75 \\
& $(1.69)$ & $(1.83)$ & $(.81)$ & $(.89)$ & $(.57)$ & $(.50)$ \\
& .68 & & .51 & & .34 & -.51 \\
Log IPR square & $(1.34)$ & & $(.90)$ & & $(.48)$ & $(.39)$ \\
& -.18 & 1.11 & .78 & -.92 & -.03 & -.37 \\
Price Control & $(1.23)$ & $(4.54)$ & $(1.79)$ & $(2.20)$ & $(.45)$ & $(.38)$ \\
& 4.02 & 2.09 & 2.68 & 1.66 & $.32^{*}$ & $.81^{* * *}$ \\
Log Innovative & $(2.16)$ & $(1.65)$ & $(1.79)$ & $(1.80)$ & $(.18)$ & $(.14)$ \\
Potential & & & & & & \\
Log Labor & $2.8^{* * *}$ & .59 & .97 & .38 & .17 & .16 \\
& $(.64)$ & $(1.52)$ & $(.63)$ & $(.74)$ & $(.23)$ & $(.19)$ \\
Log Pharmaceutical & $1.21^{* *}$ & .76 & .86 & .13 & & \\
Exports to the U.S. & $(.58)$ & $(.24)$ & $(.56)$ & $(.12)$ & & $\mathrm{Y}$ \\
Pair (Year) Fixed & $\mathrm{Y}$ & $\mathrm{Y}$ & $\mathrm{Y}$ & $\mathrm{Y}$ & & $\mathrm{Y}$ \\
Effects & & & & & & \\
\# of Obs. & 52 & 52 & 52 & 52 & 52 & 52 \\
R-square & .72 & .79 & .62 & .68 & .72 & .86 \\
\hline
\end{tabular}

